\title{
Initiates Concurrent Election Based on National Legal Votes as Presidential Threshold Indicator
}

Haedar Djidar ${ }^{*}$, Aminuddin Ilmar, Abdul Razak, Zulkifli Aspan

Faculty of Law, Hasanuddin University, South Sulawesi, Indonesia

\author{
DOI: $10.36348 /$ sijlcj.2021.v04i02.002 $\quad$ |Received: 20.01 .2021 | Accepted: 01.02 .2021 | Published: 04.02 .2021 \\ *Corresponding author: Haedar Djidar
}

\section{Abstract}

The right to vote and be elected in elections is a deviation from the sovereignty of the people which is part of the human rights of every citizen in a democratic country. Hence, to strengthening the presidential system adopted by Indonesia, the presidential threshold policy is also considered capable of reducing parliamentary domination which weakens the presidential system. The research is a normative-juridical research, using a statute, conceptual and case approaches. The results show that the limitation of voting rights with the application of the presidential threshold, the equality of citizens before the law in terms of the principle of justice can be said to not fulfill the principle of justice, namely equality in exercising the right to vote and be elected in the process of changing power. Enforcement of voting rights in terms of statutory regulations shows that the presence of the presidential threshold increases wasted votes, with many wasted votes resulting in many people's voices being not represented. The right of citizens to vote is contained in the rights of citizens guaranteed by the constitution in the form of equality in law and government.

Keywords: Constitutional Rights; Election; Presidential Threshold.

Copyright (C) 2021 The Author(s): This is an open-access article distributed under the terms of the Creative Commons Attribution 4.0 International License (CC BY-NC 4.0) which permits unrestricted use, distribution, and reproduction in any medium for non-commercial use provided the original author and source are credited.

\section{INTRODUCTION}

In order to realize a just democratic life and supporting the implementation of representative democracy, general elections become an institutional structure that is considered capable to protecting the structure of citizen sovereignty. General election is a manifestation of efforts to organize a democratic government $\left[{ }^{1}\right]$. In Indonesia, the demand for the "maturity" of the general election mechanism is undergoing a fairly dynamic constellation. Since the elections were held directly, the presidential and vice presidential elections were always preceded by legislative elections (DPR, DPD, and DPRD), meaning that the presidential and vice presidential elections were held separately from the legislative elections $\left[{ }^{2}\right]$. This is considered to have many negative impacts, especially in terms of cost efficiency, time and energy in its implementation.

\footnotetext{
${ }^{1}$ Mujani, S., \& Liddle, R. W. (2010). Indonesia: Personalities, Parties, and Voters. Journal of democracy, 21(2), 35-49.

${ }^{2}$ See Article 3 Paragraph (5) Act No. 42 of 2008 concerning the General Election of the President and Vice-President.
}

As an important instrument in democracy, general elections have a very principal position, because the holding of general elections is a real manifestation of the breath of democracy that is realized. General elections must guarantee the freedom of citizen's rights, whether to express opinion, assembly, and a right to be elected or to vote. The right to vote and be elected in elections is a deviation from the sovereignty of the people which is part of the human rights of every citizen in a democratic country $\left[{ }^{3}\right]$.

In addition to strengthening the presidential system adopted by Indonesia, the presidential threshold policy is also considered capable of reducing parliamentary domination which weakens the presidential system. On the other hand, this mechanism can "force" political parties or its coalitions to be able to seriously select candidates for president and vicePresident. As well as creating a political balance after the election by creating a coalition and opposition axis to strengthen the running of the government.

\footnotetext{
${ }^{3}$ Nur Hidayat Sardini, Restorasi Penyelenggaraan Pemilu di Indonesia. Yogyakarta: Fajar Media Press, 2011, p. 1
} 
However, behind the advantages of implementing the presidential threshold in a concurrent election, there have also been various contradictions where with this mechanism to a certain degree its application is considered to weaken the presidential system itself because the elected president will be held hostage by the interests of political parties in his coalition $\left[{ }^{4}\right]$. Furthermore, the presidential threshold can also harm new political parties that are contesting the 2019 Concurrent Elections. New political parties cannot build coalitions in determining candidates for president and vice-president because they do not have a parliamentary threshold number as an indicator, and this mechanism is considered to have eliminated the meaning of recognition, guarantee of protection and fair legal certainty, as well as equal treatment for every citizen before the law which has an impact on the loss of citizens' rights to vote intelligently and efficiently $\left.{ }^{5}\right]$.

The last reason it needs to be studied more deeply is that it is related to political rights as basic rights of citizens in nominating candidates. In this case, political rights regarding the voting rights of citizens are considered important to be protected so that the people do not choose the wrong leader. In the implementation of general elections, the people are the rightful national voters who are "entrusted" to their representatives.

In 2019, the general election will be held concurrently by holding the presidential and vicepresidential elections through the presidential threshold mechanism. This mechanism has been strengthened in a statutory regulation by making the national valid vote (25 percent) in the 2014 General Election as a reference in fulfilling the nomination threshold.

Based on the description that has been explained in the section above, the issue of this research is tendency to violate the constitutional rights of citizens as owners of sovereignty over the state. Citizens' voting rights as a basic right in the political field appear to have been injured by the implementation of the presidential threshold mechanism in the 2019 concurrent election which made the national legal vote in the 2014 election as a reference and basis.

\section{METHOD OF THE RESEARCH}

The research is a normative-juridical research; it will examine and analyze the nature of voting rights in concurrent elections based on the national legal vote as a presidential threshold indicator $\left[{ }^{6}\right]$. Types of legal

4 Lutfil Anshori, "Telaah Terhadap Presidential Threshold Dalam Pemilu Serentak 2019", Jurnal Yuridis Vol. 4 No. 1 June 2017. p. 21

${ }^{5}$ Ibid

${ }^{6}$ Soerjono Soekanto. 1986. Pengantar Penelitian Hukum, UI Press, Jakarta,. p. 44 materials used in this research are primary and secondary legal materials. Primary legal materials are obtained by examining several international instruments in relation to democracy, human rights and justice, namely the Universal Declaration of Human Rights, the Declaration of Basic Principles of Justice for Victim of Crime and Abuse of Power.

\section{Essence of Voting Rights in Concurrent Elections}

At first, democracy is an idea which presupposes that power is from, by and for the people. In a more participatory understanding, democracy is even referred to as the concept of power from, by, for and with the people. Basically, this power is recognized as coming from the people, and because of that it is the people who actually determine and provide the real direction in administering the life of the State. The whole system of State administration is basically also intended for all the people themselves, even a good state is idealized to be held together with the people in the sense of involving the community in the broadest sense. These four characteristics are included in the definition of people's sovereignty; organized for the people, by the people themselves, and by continuing to open themselves up by involving the widest possible participation of the people in running the country $\left[^{7}\right]$.

The exercise of people's sovereignty cannot be separated from general elections, because it is a logical consequence of the adoption of the principle of popular sovereignty (democracy) in the life of the nation and State. The basic principle of democratic State life is that every citizen has the right to actively participate in the political process. ${ }^{8}$ Election is an embodiment of a democratic process that must not violate the constitutional rights of citizens, because in essence democracy stands on the principle of recognition of citizenship with all its rights as citizens. General election is a conditio sine quanon for a modern democratic country, meaning that the people elect someone to represent them in the context of people's participation in the administration of the State government, as well as a series of political activities to accommodate the interests or aspirations of the people. In the context of humans as individual citizens, general elections mean the process of temporarily handing over their political rights. This right is a sovereign right to participate in running the administration of the State $\left[{ }^{9}\right]$.

\footnotetext{
${ }^{7}$ Jimly Assiddiqie (a), "Demokrasi dan Nomokrasi: Prasyarat Menuju Indonesia Baru", Hukum Tata Negara dan Pilar-Pilar Demokrasi (Serpihan Pemikiran Hukum, Media dan HAM), cet. I, (Jakarta: Konstitusi Press, 2005), pp. 293-294.

${ }^{8}$ Dahlan Thaib, Implementasi Sistem Ketatanegaraan Menurut UUD 1945, Liberty, Jakarta, 1993, p. 94

${ }^{9}$ Miriam Budiarjo, Hak Asasi Manusia Dalam Dimensi Global, Jurnal Ilmu Politik, No. 10, 1990, Jakarta, p. 37.
} 
The Economist Intelligence Unit's Democracy Index

167 countries scored on a scale of 0 to 10 based on 60 indicators

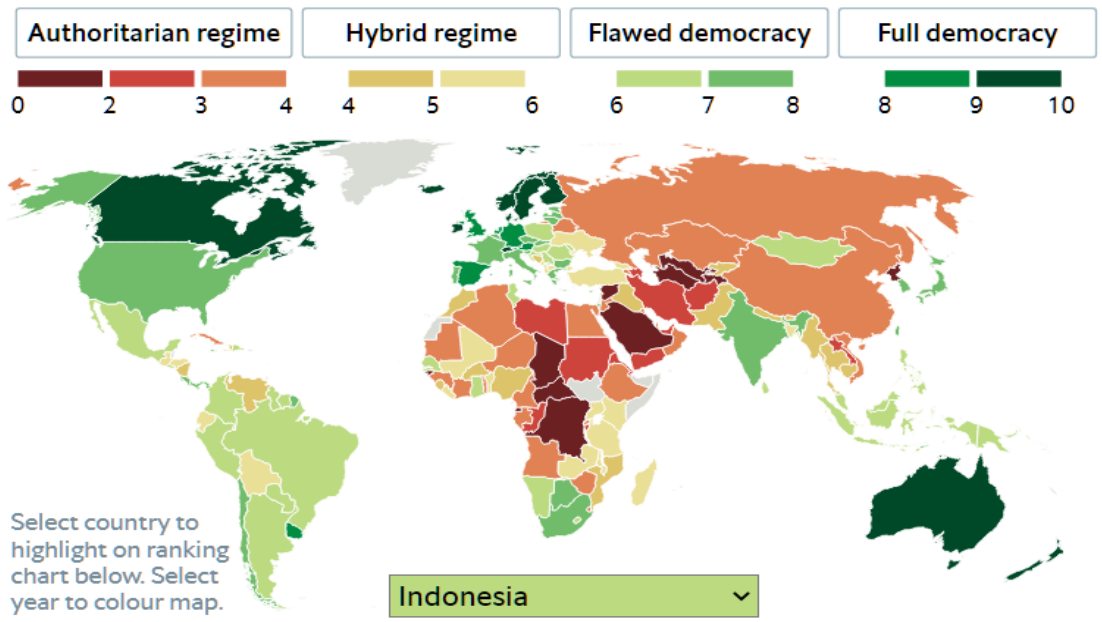

The restrictions on political channels for voters has an impact on decreasing the level of public participation in participating in general elections because they think they cannot vote for their candidates due to the effect of these restrictions. Meanwhile, as the owner of supreme sovereignty in a democratic country, the people's right to vote must be possible to elect candidates who have been provided constitutionally and avoid political-oligarchic tastes. It is necessary to pay attention to this, because the people as voters have full rights to use political channels and access in order to elect appropriate Candidates for President and Vice President.

In general elections, the political rights of citizens are very important to be protected so that their voting rights can be distributed, the fact is that the political rights of citizens cannot be fully accommodated due to restrictions so that the level of citizen participation is still minimal and votes are not represented due to wasted votes due to presidential threshold and parliamentary threshold.

The ownership of the right holder and its implementation must be free from all kinds of discrimination as determined by Article 2 of the International Covenant on Civil and Political Rights as well as the General Declaration of Human Rights. The concept of anti-discrimination in the implementation of the general election is a form of the foundation for the principles of justice by which all people will receive equality in channeling their political rights, without discrimination and freely determining their choice in channeling their voting rights through the general election process so that the general election is a manifestation of sovereignty people in a democratic country can be realized.

By its importance, a number of legal instruments were prepared, such as the regulation of
General Election Commission to provide guarantees that voters could exercise their voting rights on election or voting day. However, the main thing is the availability of an accurate voter list, which will then be used as the basis for drafting a number of improvements to voter registration for the next election.

Technically, a form of guarantee for voters to be able to use their voting rights is the availability of an accurate voter list. This is because the procedure or requirement for voters to be able to exercise their right to vote is to be registered in the voter list. If voters are registered in the voter list, on polling day they are guaranteed to be able to exercise their voting rights. Likewise, on the other hand, if voters are not registered in the voter list, they have the potential to lose their voting rights.

\section{Concurrent Elections in 2019 and the Effects of Presidential Threshold}

Design of concurrent election between the presidential and legislative elections in 2019 is motivated by the birth of the Constitutional Court's Decision No. 14 / PUU-XI / 2013 dated January 23, 2014. Thus the presidential threshold remains a concept that applies in the presidential and vice presidential elections $\left[{ }^{10}\right]$. The presidential threshold policy is related to the parliamentary threshold policy that replaces the electoral threshold $\left[{ }^{11}\right]$, one of which is

\footnotetext{
${ }^{10}$ The Presidential Threshold in article 9 does not contradict the 1945 Constitution of the Republic of Indonesia because it discusses candidacy (pre-election), not regarding the determination of the winning number (post-election) as regulated in Article 6A paragraph 3 and 4 of the 1945 Constitution.

${ }^{11}$ Janedri M. Ghaffar, Politik Hukum Pemilu, Jakarta: Konstitusi Pres, 2012, p. 33
} 
used to strengthen the presidential system by building a simple party system $\left[{ }^{12}\right]$.

The provision of presidential threshold should not be needed because the purpose of implementing the presidential threshold is to present a simple party system and in order to garner majority support from the parliament for the elected president and vice-president, which are automatically carried out from the results of the concurrent election. The existence of concurrent elections is actually a step and effort to support the arrangement of the presidential government system. The hope is that the concurrent election will be followed by a coattail effect and solid coalition ranks so that the political party or a combination of political parties can win the presidential and vice presidential elections and simultaneously win votes in parliament so that parliamentary support is maximized. Or if this coattail effect does not occur, at least the coalition building will be more solid than the non-simultaneous elections which have proven to be very loose in nature so that the president's policies do not always get support from coalition partners. Solid support due to simultaneous elections is a plus in building a stable and effective presidential system of government. According to Didik Supriyanto, the concurrent election of the national parliament and the president had 2 (two) effects: the first, early coalition, because political parties were forced to form a coalition early to be solid in order to win the competition; the second, there is a coattail effect where the election of the president will affect the electability of the national parliament $\left[{ }^{13}\right]$.

The application of the presidential threshold contains a consequence of the loss of opportunities and rights of citizens through political parties that do not meet the determined numbers to nominate candidates. Therefore, it is necessary to pay attention, in accordance with the principles of democracy, in determining the limit of the presidential threshold; it should not be detrimental to certain community groups, especially minorities. Determining the presidential threshold must take into account the diversity of society which is reflected in political aspirations $\left[{ }^{14}\right]$.

The problem of 2019 Election does not solely lie in the simultaneous implementation of the

\footnotetext{
${ }^{12}$ Gringer, D. (2008). Why the national popular vote plan is the wrong way to abolish the Electoral College. Colum. L. Rev., 108, 182.

${ }^{13}$ Didik Supriyanto, "Pemilu Serentak Versi MK Justru Merepotkan dalam Indra", Pahlevi (edt), Pemilu Serentak Dalam Pemerintahan Indonesia, (Jakarta: P3DISetjen DPR RI dan AzzaGrafika,2015) p. ix.

${ }^{14}$ I Dewa Made Putra Wijaya, "Mengukur Derajat Demokrasi Undang-Undang Nomor 42 Tahun2008 tentang Pemilihan Umum Presiden dan Wakil Presiden", Jurnal IUS, Vol. II No. 6 December2014, p.
}

presidential and legislative elections because this is a necessity of the original intent of the constitution itself, but rather the choice of the scheme or variant of the concurrent election itself $\left[{ }^{15}\right]$.

Putting the principle of state obligation must get attention to everyone who questions human rights. It is important to socialize this principle to ensure that the implementation of human rights is under the jurisdiction of state obligations. The implementation of state obligations is not only to apply what is contained in international treaties and which later becomes part of its national law, but what is more important than that is ensuring its implementation. Third, there is no obligation without responsibility. Laying out the principle of state obligation of course also relates to state responsibility.

The consistency of the entire series of agreements and obligations always demands responsibility as a logical partner. If the State fails to fulfill its promises and obligations, then the State is also held accountable. The fourth, as the party that promised, the state not only always has the potential, but factually denies or violates its own promise to respect, protect and fulfill human rights. With this, it becomes clear that human rights violations are the responsibility of the state $\left[{ }^{16}\right]$.

The holding of concurrent elections in 2019 left many problems, added with a judicial review. In this relation, there are at least 10 advantages of the concurrent election scheme that separates national concurrent elections and local concurrent elections $\left[{ }^{17}\right]$.

The first, the scheme of concurrent election that separates national and local ones promises to form a more effective election result government because the elected president and the majority power in DPR come from the same political parties or coalition of political parties. This is possible because the scheme of concurrent election hypothetically produces a coattail effect, which should not only be understood in the context of the influence of the popularity of the presidential candidate on the supporting political parties in the parliamentary election results, but also local concurrent election results that are influenced by the national concurrent election results.

\footnotetext{
${ }^{15}$ Syamsuddin Haris. The views expressed as experts presented by the Constitutional Court at the Request for Review of Act No. 7 of 2017 concerning Elections against the 1945 Constitution, 17 October 2019 in the Constitutional Court.

${ }^{16}$ Basically, the state is a party that agrees and is at the same time a violator of human rights in accordance with the declarations and agreements it has signed.

${ }^{17}$ Aminuddin Ilmar, (2014). Hukum Tata Pemerintahan. Jakarta: Prenada Media.
} 
The second, if the national concurrent election results government has a good performance, then the local concurrent election results are likely to be the same as the national concurrent election results. It means that the election is won by the same candidate and/or party, which in turn results in synergy and effectiveness of national-local-regional government.

The third, on the other hand, if the government of the national concurrent election results is poor, then there is an opportunity for the public to punish the ruling political party or coalition of political parties through the momentum of local simultaneous elections by not re-selecting them.

The fourth, the tendency to form political coalitions solely on the basis of short-term political interests can be minimized because political parties are "forced" into coalitions before the results of legislative elections are made, which in turn can also reduce the tendency for transactional politics to take place.

The fifth, local political issues that have tended to be drowned in the frenzy of national elections, including during the Constitutional Court version of the simultaneous elections on 17 April 2019, can be raised through local simultaneous elections.

The sixth, elected representatives of the people and executive officers are expected to be more accountable because their performance and their supporting parties are re-evaluated in a relatively short time (30 months).

The seventh, scheme of concurrent election separating the recommended national and local elections would simplify the number of parties thus promising the formation of a moderate multiparty system.

The eighth, the recommended alternative scheme promises greater opportunities for local political elites whose performance and leadership are successful in competing to become political elites at the national level.

The ninth, national concurrent elections that are separate from local simultaneous elections are expected to reduce the potential for transactional politics as a result of the institutionalization of political opportunism as it has been. There is no longer any chance for DPRD members to participate in regional election competitions because the DPRD elections take place simultaneously with the regional head elections.

The tenth, the national concurrent elections that are separate from local simultaneous elections are expected to improve the quality of the results of people's choices to become more rational because voters attention does not have to be divided on too many choices at once at a very limited time in the voting booths. That way, voters have more free time to make a thorough decision before casting their vote or marking their choice.

The Indonesian Institute of Sciences (LIPI) conducted a survey on 2019 Election and Democracy in Indonesia, where this survey aims to capture public perceptions and figures regarding their evaluation of the 2019 Concurrent Election which is a milestone for new democracy in Indonesia. The 2019 Concurrent Election Survey took place April 27 to May 5, 2019. Using the multistage random sampling method, the surveyors involved 1500 respondents from 34 provinces with a margin of error of approximately 2.53 percent and a confidence level of 95 percent. This survey also captured the perceptions of 119 figures from various backgrounds (academics, politicians, journalists, businessmen, cultural figures, community leaders, religious leaders, women issue activists, NGOs and youth) in five major cities in Indonesia, namely Jakarta, Padang, Pontianak, Surabaya, and Makassar with a purposive sampling method. The survey results showed that only 16.9 percent of respondents said they chose the candidates for the presidential and vice presidential candidates. Meanwhile, 74 percent of respondents to the public survey and 86 survey figures felt that they were troubled by technical matters during the 2019 Concurrent Election $\left[{ }^{18}\right]$.

Based on the decision of the Constitutional Court, it can be concluded that a constitutional election is an election which is held concurrently between the executive and the legislative election. The conception of concurrency ordered by the Constitutional Court was that the elections for the President, DPR and DPD had to be carried out concurrently. Academically, the concept of concurrent elections only applies in the presidential government system. The core of the concept is to combine the implementation of the Legislative and the Executive Election in one Election Day. The goal is to create a congruent election result government. That is, the election of executive officials who get legislative support so that the government is stable and effective. In a parliamentary government system, there is no need for concurrent elections, because once an election, members of the legislature as well as executive officers are already elected. This is because a political party or coalition of political parties that wins the election or controls the majority of seats in parliament, has the right to appoint the prime minister and other executive officials $\left[{ }^{19}\right]$.

18 http://lipi.go.id/berita/Evaluasi-Pemilu-Serentakdalam-Temuan-Survei-LIPI/21763

${ }^{19}$ Didik Supriyanto. The views expressed as an expert presented by the Constitutional Court in the Request for Review of Act No. 42 of 2008 concerning the General Election of President and Vice President 
The current electoral format locates a legislative election period every five years. The time interval of five years from one election to the next eliminates the critical power of voters to control the performance of political parties through elections. The assumption is that voters will punish political parties whose performance is poor (ranging from not keeping campaign promises to being involved in a corruption scandal) in the next election. The poor performance of political parties is mostly recognized and felt by voters in the second or third year of service. At that time, however, voters could not punish political parties effectively, because at that time there were no elections. However, when the election came back in the fifth year, the poor performance of political parties had disappeared, either because voters forgot the performance of political parties as a whole deteriorated, or voters were dazzled by the campaign. As a result, voters are ineffective in dropping the sledgehammer on political parties, so that political parties are not motivated to improve their performance.

Agus Mellaz delivered a more comprehensive elaboration on some of the advantages of implementing concurrent executive-legislative elections. According to Agus Mellaz, various factors become the background, as well as being considered as an advantage of implementing the general election concurrently. In many countries it produces trends; the first, the level of legitimacy of the elected president becomes strong, both in popular (voter) and parliamentary support. The second, the possibility of the president being directly elected in the first round (especially in the plurality system). The third, the effect of party system simplification, through; (a) incentives for political parties to form alliances, form coalitions, and join both in the presidential and legislative elections. (b) narrowing the area of competition and the number of political parties in gaining legislative seats $\left[{ }^{20}\right]$.
In the decision of the Constitutional Court No. 55/PUU-XVII/2019, it gives a new nuance to our upcoming election vote, that the simultaneous election encourages the formation of a congruent government because parties are forced to build a coalition early before the election. Simultaneous elections lead to a coattail effect, namely the tendency for presidential elections and their electability to affect the election and electability of parliamentarians. Obviously, the election of candidate for President A affects the electability of candidate members of parliament from the party or coalition of parties that nominated Candidate for President A. In concurrent elections, voters will elect the president as well as the party or coalition of parties supporting the president. Voters feel that choosing the president is more important than electing members of parliament.

\section{CONCLUSION}

General election is a manifestation of the people's sovereignty, so that with the general election, citizens can exercise their right to vote intelligently (using presidential coattail \& political efficacy) and efficient. With the limitation of voting rights with the application of the presidential threshold, the equality of citizens before the law in terms of the principle of justice can be said to not fulfill the principle of justice, namely equality in exercising the right to vote and be elected in the process of changing power.

Enforcement of voting rights in terms of statutory regulations shows that the presence of the presidential threshold increases wasted votes, with many wasted votes resulting in many people's voices being not represented. The right of citizens to vote is contained in the rights of citizens guaranteed by the constitution in the form of equality in law and government. The presidential threshold resulted in quite a lot of votes being wasted so that the election results were not proportional (unable to represent the real votes of the people).

${ }^{20}$ Ibid 